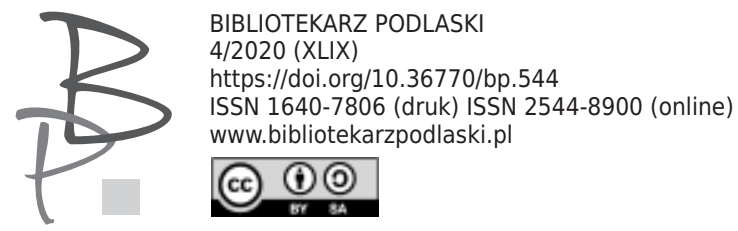

\author{
Bernadetta M. Puchalska-Dąbrowska* \\ Uniwersytet w Białymstoku \\ https://orcid.org/0000-0001-6909-4373
}

\title{
Królewicz wśród królów. Portrety władców zachodnioeuropejskich w staropolskich relacjach z podróży Władysława Wazy (1624-1625)
}

A prince among kings. Portraits of Western European rulers in old Polish accounts from Władysław Vasa's travels (1624-1625)

Abstract: The aim of the article is to analyse literary images of rulers in three accounts of Prince Władysław Vasa's travels to the countries of Western Europe in the years 1624-1625. The young Vasa's retinue included future authors of the peregrination reports: Stefan Pac - a writer, later treasurer and Grand Chancellor of Lithuania, Albrecht Stanisław Radziwiłł - Grand Chancellor of Lithuania, and Jan Hagenaw of Warmia. The silhouettes of Western European monarchs, presented in the context of specific events, were treated in a fragmentary way and included elements interesting to the author. On the other hand, the methods used to present the Polish prince, according to the "promotional" strategy adopted by diarists, were aimed at showing the hero as an indi-

\footnotetext{
Bernadetta M. Puchalska-Dąbrowska - prof. dr hab. pracownik Instytutu Filologii Polskiej Uniwersytetu w Białymstoku. Autorka m.in. monografii: Bohaterowie Wysp Brytyjskich jako wzorce świętości w hagiografii polskiej XVI-XVII wieku (Białystok 2009); Beda Czcigodny i bohaterowie historii kościelnej narodu angielskiego w polskim piśmiennictwie religijnym XVI-XVIII wieku (Warszawa 2017).
} 
vidual worthy of being "among kings", capable - thanks to his skills - of finding his place in court.

Keywords: Władysław Vasa, prince, diary, travel, court, ruler.

Istotnym aspektem postrzegania świata, zauważanym przez badaczy dawnych relacji z podróży, jest obserwacja złożoności sfery społecznej¹. Poszczególne jej elementy bywają poddawane oglądowi z uwzględnieniem ich specyficznych stratyfikacji i odmienności mentalnościowych² ${ }^{2}$ Do ważnych wyróżników sfer społecznych należą między innymi wszelkiego typu urządzenia wspólnotowe i kulturowe, instytucje władzy, organizacje życia religijnego oraz mechanizmy ich działania ${ }^{3}$. Naturalnym obszarem rejestrowania tych zjawisk są teksty powstałe $\mathrm{w}$ związku z procesem przemieszczania się w przestrzeni na przykład diariusze podróży - jak również fragmenty zapisków pamiętnikarskich, w których autor wspomina przeżycia związane z odbytą drogą ${ }^{4}$.

W piśmiennictwie podróżniczym interesującego nas okresu wiele miejsca poświęca się obserwacjom związanym z wizytami na dworach królewskich lub książęcych. Rozwój koncepcji monarchii absolutnej i suwerennej w XVII stuleciu doprowadził do wzmożenia wiary w nadprzyrodzone źródła władzy monarszej ${ }^{5}$, dzięki czemu postacie panujących stawały się atrakcyjnym obiektem oglądu i opisu. Istotnym czynnikiem skłaniającym do wizyt na dworze była także indywidualność władcy przydająca splendoru otoczeniu, a nawet przysparzająca sławy - rozmaicie pojmowanej - danemu obszarowi ${ }^{6}$. Zawieranie znajomości z lokalnymi panującymi stanowiło nadto element wykształcenia

1 B. Rok, Percepcja rzeczywistości europejskiej staropolskich peregrynantów połowy XVIII wieku, [w:] Staropolski ogląd świata. Tożsamość i odmienność, red. B. Rok, F. Wolański, Toruń 2011, s. 9.

2 Tamże, s. 10.

3 Tamże.

4 Tamże.

5 M. Markiewicz, Sakralizacja władzy królewskiej w czasach nowożytnych, [w:] Staropolski oglad świata. Kultura staropolska - poszukiwanie sacrum, odnajdywanie profanum, red. B. Rok, F. Wolański, Toruń 2013, s. 27.

6 B. M. Puchalska, Obraz dworów zachodnioeuropejskich w polskiej literaturze pamiętnikarskiej XVI i XVII wieku, Białystok 2000, s. 63. 
młodego szlachcica, czego dowodem choćby treści ojcowskich instrukcji dla synów wyruszających w podróż zagraniczną ${ }^{7}$ Z kolei z urzędu stykali się z koronowanymi głowami uczestnicy legacji poselskich i towarzyszące im osoby8.

Królewicz Władysław Waza, pierworodny syn Zygmunta III, projektował swą podróż po Europie od roku 1622. Doświadczenia kampanii chocimskiej sprzed dwóch lat, jak również towarzyszące jej poważne komplikacje zdrowotne zaowocowały prywatnym ślubem odbycia pielgrzymki do Loreto - jako aktu dziękczynienia za odniesione zwycięstwo oraz ocalenie życia9. Poza względami religijnymi, czynnikiem motywacyjnym była chęć poznania krajów Europy Zachodniej, znanych ze słyszenia i - zapewne - lektury relacji z podróży magnackich i szlacheckich ${ }^{10}$. Następcę tronu interesowała także sztuka wojenna ${ }^{11}$. Nie najmniej ważną intencją podjętej peregrynacji była - jak słusznie stwierdzają niektórzy badacze - promocja dynastii, własnej osoby i reprezentowanego przez siebie kraju ${ }^{12}$.

Po uzyskaniu - nie bez przeszkód - ojcowskiej zgody ${ }^{13}$, królewicz wyruszył w drogę, zaopatrzony w stosowne instrukcje i listy polecające. W pięćdzie-

7 Tamże, s. 64.

8 Tamże.

9 A. Przyboś, Wstęp, [w:] Podróż królewicza Władysława Wazy do krajów Europy Zachodniej w latach 1624-1625 w świetle ówczesnych relacji, oprac. A. Przyboś, Kraków 1977, s. 14.

10 Tamże, s. 14.

11 Tamże.

12 Charakter podróży Władysława Wazy nie został dotąd określony jednoznacznie. Zdaniem Dariusza Wajsa, jest to zagadnienie bardziej skomplikowane, aniżeli wynika to z literatury wpisującej peregrynację w zjawisko tzw. Grand Tour. Zdaniem wspomnianego badacza, „Określenie jej mianem podróży edukacyjnej [...] spowodowało, że zapomniano niejako o instrukcji króla Zygmunta III Wazy dla Albrychta Stanisława Radziwiłła z maja 1624 roku, która określała wstępny charakter podróży królewicza. [...] Monarcha wskazywał jako najważniejszy cel pozytywną propagandę na rzecz króla, królewicza i całej rodziny królewskiej. [...] Drugim elementem propagandy Wazów było rozsławienie zwycięstwa nad Turkami pod Chocimiem w 1621 roku. [...] W Instrukcji zaznaczono, że królewicz Władysław miał także odbyć pielgrzymkę. [...] Poznawcza warstwa podróży królewicza, nadająca jej z pozoru charakteru podróży edukacyjnej, nieokreślona w Instrukcji, była efektem działań oraz zainteresowań królewicza Władysława i wychodziła poza ramy wspomnianego dokumentu. [...] Instrukcja [...] nadawała podróży królewiczowskiej charakteru podróży propagandowofamilijnej, podczas której królewicz Władysław miał rozpowszechniać na dworach europejskich pozytywny wizerunek własnej osoby oraz rodu panującego w Rzeczypospolitej, bazując na wspomnianym już zwycięstwie chocimskim”. Zob. D. Wajs, Charakter podróży królewicza Władysława Wazy z lat 1624-1625, [w:] Rzeczpospolita Wazów (1588-1648-1668). I Kongres Badaczy Epoki Wazów, Olsztyn 6-8 września 2018, oprac. A. Korytko i in., Olsztyn 2018, s. 103-106. 
sięcioosobowym orszaku młodego Wazy znaleźli się przyszli autorzy relacji z jego podróży: Stefan Pac - pisarz, a następnie podskarbi i podkanclerzy wielki litewski ${ }^{14}$, Albrycht Stanisław Radziwiłł - kanclerz wielki litewski, główny odpowiedzialny za osobę i orszak królewicza ${ }^{15}$ oraz pochodzący z Warmii Jan Hagenaw - dworzanin Radziwiłła ${ }^{16}$. Pozostawione przez nich teksty stanowią podstawowe i najobszerniejsze źródła do poznania szczegółów peregrynacji następcy tronu polskiego. Są to również cenne dokumenty zawierające opisy współczesnych dworów zachodnioeuropejskich - rezydencji i ich wyposażenia, ceremoniału, rozrywek, jak również relacji łączących Wazów z Habsburgami oraz ich krewnymi w Niemczech, Hiszpanii, Niderlandach i Włoszech ${ }^{17}$. Możliwość spotkań z lokalnymi panującymi pozwoliła młodemu podróżnikowi na zaznajomienie się z rozmaitymi formami rządów - od absolutystycznych po republikańskie, nawiązanie bliższych kontaktów oraz czynienie porównań. Owocem tych wizyt była między innymi bliższa sympatia do dynastii habsburskiej bądź niechęć do kurii rzymskiej18.

Prezentacje panujących zachodnioeuropejskich stanowią integralną część każdego spośród analizowanych przekazów. Ze względu na znaczną ilość sylwetek pojawiających się w poszczególnych relacjach - mniej lub bardziej obszernych prezentacji doczekali się między innymi papież Urban VIII, cesarz Ferdynand II, infantka Izabela Klara Eugenia oraz liczni książęta lokalni - zaistniała konieczność dokonania selekcji. Zasadniczym kryterium doboru postaci stała się treść instrukcji Zygmunta III dla Albrychta Stanisława Radziwiłła zawierająca następujące zalecenia:

W czasie drogi i całej tej wędrówki jw.jm. książę będzie się trzymał tej wytycznej, żeby stąd zmierzać z Najjaśn. Królewiczem [...] do Pragi lub Wiednia do Naj-

13 Jako powody niezdecydowania Zygmunta III Adam Przyboś wskazuje ewentualne ryzyko pomniejszenia sławy syna po zwycięstwie chocimskim, niebezpieczeństw w drodze wynikających np. z toczącej się wojny w Niemczech czy wywołania rywalizacji mogącej zaszkodzić dynastii. Zob. tamże, s. 15.
14 Tamże, s. 19.
15 Tamże, s. 22.
16 Tamże, s. 23.
17 Tamże, s. 31.
18 Tamże, s. 33. 
jaśn. Cesarza rzymskiego, dalej do Innsbrucka do Najjaśn. Arcyksięcia Leopolda, potem do Brukseli do Belgii, do Najjaśn. Infantki Hiszpańskiej Eugenii Izabeli, a w końcu do Włoch, jeśli czasy i drogi na to pozwolą. [...] Powracając z Rzymu do kraju skieruje swe kroki [...] do wielkiego księcia Toskanii do Florencji [...]. Wracając zaś znowu uda się do J.C. Mci i do Arcyksiążąt Leopolda i Karola, jeśli pozwoli na to dogodność drogi ${ }^{19}$.

Analiza literackiego sposobu konstrukcji bohaterów pozwala na wyodrębnienie sytuacji, w których dochodzi do bezpośredniego spotkania autora relacji z osobą monarchy. Są to w przeważającej większości konteksty oficjalne - ceremonialne wjazdy i audiencje z towarzyszącą im oprawą etykietalną. Staropolscy narratorzy portretują władców kroczących w uroczystych pochodach, uczestniczących w nabożeństwach, scenach powitania i pożegnania. Nieodzownym zabiegiem jest przy tej okazji rejestrowanie wykonywanych gestów, będących swoistymi komunikatami przekazywanymi otoczeniu. Sporo miejsca w zbadanych przekazach poświęca się także rozrywkom, jak na przykład tańce, polowania czy biesiady. W obrębie zainteresowania pamiętnikarzy znajduje się także postać Władysława Wazy - tytułowego „królewicza wśród królów" - wchodzącego w interakcje ze swymi gospodarzami, poddawana osobnemu oglądowi i ocenie. Zdaniem Krystyny Stasiewicz, centralną postacią dziennika podróży Jana Hagenawa jest właśnie następca tronu polskiego ${ }^{20}$. Autorom przyświecały cele dokumentacyjne i empiryczne ${ }^{21}$, jak również - na co wskazuje treść analizowanych zapisów - promocyjne i propagandowe.

\section{Audiencje}

Naturalnym kontekstem prezentacji osób panujących są oficjalne spotkania autorów relacji poprzedzające bezpośrednią wizytę królewicza oraz sceny audiencji udzielanych polskiemu następcy tronu. W sprawozdaniu z wizyty na dworze w Brukseli u infantki Izabeli Klary Eugenii, zarejestrowanym w formie

19 Instrukcja króla Zygmunta III dla Albrychta Stanisława Radziwilta, kanclerza litewskiego, dana w Warszawie w maju 1625, [w:] Podróż królewicza..., s. 422, 426.

20 K. Stasiewicz, Obraz tych samych spraw i miejsc przedstawiony w diariuszach podróży z XVII i XVIII wieku (Hagenaw, Billewicz, Charkiewicz), [w:] ,W Wsystko tu najdzie, co wy macie w głowie”. Świat prozy staropolskiej, red. E. Lasocińska, A. Czechowicz, Warszawa 2008, s. 340.

21 Tamże, s. 341. 
trzecioosobowej - i częściowo również mowie niezależnej - Stefan Pac ukazuje autentyczne zainteresowanie bohaterki osobą młodego Wazy. Jak wynika z tekstu, informacje o dokonaniach wojennych królewicza i poprzedzająca go sława dotarły do Izabeli, wzbudzając jej ciekawość i chęć bezpośredniego spotkania. Tym tłumaczy się również gwałtowna reakcja infantki na propozycję podjęcia gościa - przybywającego jako pielgrzym - incognito, a zatem bez należnych mu honorów. Diarysta pisze:

Ja po włoskum te kilka słów do Infanty mówił, na co ona po hiszpańsku odpowiedziała, iż wie dawno, że jej Królewic J.M. tę łaskę chce uczynić być u niej, czego ona sobie dawno życzyła, aby tak zacnego i sławnego Królewica poznać mogła, i że z wielką chęcią nań czeka, a prawie już sobie oczy wypatrzyła wyglądając go. [...] Tum znowu wniósł prośbę imieniem Królewicowym, aby raczyła moderować te honores i solennes exceptiones ${ }^{22}$. [...] Otóź prosi [Władysław - B. M. P. D.], aby go w tym jego przedsięwzięciu zachowała.

Na co ona mi odpowiedziała: „Jak to może być - powiada - aby syn króla tak wielkiego i mój tak bliski powinny miał być nieznajomy w domu moim? Mam ja nadzieję, że mi tego nie uczyni, ponieważ i w Wiedniu u cesarza, i w Mnichu u książąt bawarskich nie taił się; toż rozumiem, że tu, będąc jako w domu swoim, da sobie honor i usługę należną uczynić23.

Jak odnotował kronikarz, królewicz Władysław - wbrew pierwotnym intencjom („,ma insze direggi drogi swej, odprawować ją jako pielgrzym, nie jako syn królewski") ${ }^{24}$ uszanował, jakkolwiek z pewnymi zastrzeżeniami, życzenie gospodyni - prosił o nieujawnianie swej tożsamości przed wyjeżdżającymi mu naprzeciw hiszpańskimi grandami („Królewic [...] nie chciał się z tymi pany grandami ceremonijować, którzy się wysoko niosą al pari udzielnym książętom i synom królewskim. [...] Nie zdało się tedy temu, który jest samą rzeczą grande di Polonia, stowarzyszać się a tanto minus konkurować z tymi pany, grandi di Hispania" ${ }^{25}$. W czasie wjazdu doszło do nieprzyjemnego incydentu-

\footnotetext{
22 Tamże, s. 154.

23 Tamże.

24 Tamże.

25 Tamże, s. 161.
} 
na skutek nieuwagi woźnicy jadącego zbyt blisko bramy pałacu młody Waza został zraniony szpadą jednego z towarzyszących karecie jeźdźców. Diarysta zarejestrował moment wahania bohatera („Nie wiem, co czynić, jeśli mam iść z tym razem do Infanty, czyli do swego złożenia, żebym się dał opatrzyć") ${ }^{26}$, po czym z satysfakcją odnotował własne, dyplomatyczne rozwiązanie problemu, mające przydać heroizmu książęcemu peregrynantowi:

„Dobrze by, żebyś W.K.M. odprawił jakokolwiek te ceremoniją pokrywając ból, caedet to in laudem et commendationem [wypadnie to na chwałę i zalecenie] męstwa u tych obcych ludzi WKMci". I tak wziąłwszy u książęcia pana kanclerze kijek niewielki z drzewa indyjskiego, który książę w drodze zwykł był zawsze w ręku nosić, na tymże trochę się wspierając, szedł przeciwko Infancie ${ }^{27}$.

W scenie powitania Władysława autor odnotowuje szczegóły dworskiego ceremoniału, szczególną uwagę zwracając na przejawy tzw. kultury ge$\mathrm{stu}^{28}$, wystawiające jak najlepsze świadectwo królewskiemu podróżnikowi jako znawcy dworskiej etykiety i miejscowych zwyczajów. Rejestruje także nacechowaną współczuciem reakcję Izabeli na incydent podczas wjazdu - wyczuwając potrzeby gościa, infantka nie przedłuża audiencji, umożliwiając opatrzenie rany i wypoczynek:

Zeszli się w sali jednej [...]. Tam się z sobą przywitali. Królewic J.M., jako się kawalerowi godziło, uczynił jej nisko rewerencyją, przerzekłszy kilka słów del complemento. Infanta też mu wzajem odpowiedziała cerą bardzo miłą, jako się godziło do tak zacnego gościa. Puścił ją potem Królewic po prawej ręce i podług zwyczaju tamtych krajów prowadzenia pań zacnych podał jej ręki, żeby się na niej sparłszy, szła. Długo się tego zbraniała, ale gdy królewic prosił, żeby mu ten honor uczyniła, lekko się trzymając ręki królewicowej szła tak z nim aż do swego pokoju, gdzie potem pod baldechinem pospołu z sobą usiedli, rozmawiając o tym przypadku królewiczowym, którego Infanta bardzo żałowała. Dlategoż niedługo ze sobą bawiąc, a czas dając, aby

26 Tamże, s. 162.

27 Tamże, s. 162.

28 Szczegółowe analizy dotyczące kultury gestu w okresie staropolskim poczyniła m.in. Hanna Dziechcińska w pracy Ciało, strój, gest w czasach renesansu i baroku, Warszawa 1996. 
Królewic J.M. sobie wczas uczynił, rozeszli się. Prowadziła Infanta przez dwa pokoje Królewica, chcociaj i on tego jej bronił. Potem książęta i dwór wszystek do złożenia królewicowego, gdzie zaraz dał się opatrować, oberznąwszy but on na nodze.

Postawa szacunku gospodyni wobec gościa oraz zatroskanie wywołane niefortunnym zdarzeniem znajdują także odzwierciedlenie w relacji Albrychta Stanisława Radziwiłła. Skrótowe zapisy, ustępujące miejsca obszernemu opisowi wypadku królewicza, przybierają formę lakonicznych stwierdzeń typu: „Izabela rozkazała, aby z nim tak jak z samym królem hiszpańskim obchodzono [...] mocno się z tego przypadku zasmuciła, a ów drabant na gardle był ukarany" ${ }^{\prime 2}$. Nie zabrakło też miejsca na podkreślenie bohaterskiej postawy Władysława, który w czasie audiencji „przez całą godzinę stał i posadzkę krwią zbroczył" ${ }^{30}$. Jan Hagenaw dodaje intrygujący szczegół dotyczący powierzchowności Izabeli - skłonna do dewocji infantka przyjmuje młodego Wazę „w habicie mniszym karmelitanek"31, i zwraca uwagę na nieformalne reakcje władczyni: „wybiegła naprzeciw Królewicza i, uściskawszy go serdecznie, zaprowadziła za rękę do obszernej sali”32. Strój nielicujący z książęcą godnością (,zakonna cera”) jako podstawowy rys charakterystyki infantki wspomina także Samuel Twardowski w wierszowanej relacji z podróży:

Sama w tej ozdobie,

Która nie kondycyi wielkiej jej należy,

Ale w prostej i grubo zakonnej odzieży

Panien karmelitańskich. Że jednak królewna

Choć w tej umbrze, sama twarz ideą jej pewna

Coś boskiego na ziemi ${ }^{33}$.

Prezentacje pozaetykietalnych, spontanicznych gestów dodatkowo służą wystylizowaniu portretu postaci panującego, jego charakteru i usposobienia,

29 Tamże, s. 164.

30 Tamże.

31 Tamże, s. 167.

32 Tamże.

33 Tamże, s. 169. 
jak również uwydatnieniu stosunku do królewskiego gościa. Stopień uszczegółowienia narracji zależy od pozycji diarysty w orszaku młodego Wazy. Nienależący do bezpośredniego otoczenia Władysława ${ }^{34}$ Jan Hagenaw-dworzanin przyjmuje postawę biernego obserwatora - wspomina „szczególną radość” wyrażaną przez obie strony, niekiedy tylko rozbudowując opowiadanie o dalsze detale ${ }^{35}$. Bliżej związany z bohaterami zdarzenia Stefan Pac wzbogaca sprawozdanie o opis konkretnych zachowań: „Tam Arcyksiążę wpadłszy, bieżał wprzód Cesarza witać, a za nim Królewic. Ale Cesarz odepchnąwszy brata, rzucił się zaraz do Królewica i obłapił go mile jako syna własnego"36. Na temat relacji ojcowsko-synowskich wypowiada się również Albrycht Stanisław Radziwiłł: „Cesarz, który bardzo kochał Królewica jako syna własnego, znowu nas z wielkimi przyjął honorami" ${ }^{37}$. Elementem uzupełniającym pozaoficjalny portret cesarza jest przedstawienie go w roli przewodnika oprowadzającego gości z Polski po sekretnym skarbcu Habsburgów: „Cesarz J.M. sam, jako wielkiej dobroci i ludzkości pan, wszystkie co przedniejsze rzeczy nam pokazował"38.

W strukturze diariuszowych zapisków z oficjalnych spotkań obecne są fragmenty zawierające elementy oceny zachowań królewicza. $Z$ reguły - co można uznać za komponent strategii „promocyjnej” - formułowane przez autorów opinie są pozytywne, zaś w sytuacjach wątpliwych diarysta opowiada się po stronie Władysława. Tak dzieje się na przykład w opisie wizyty na dworze w Brukseli, w czasie której polski gość nie zastosował się do wymagań protokołu. Oddajmy głos Stefanowi Pacowi:

Odprawił ten swój wjazd i witanie Infanty Królewic bardzo porządnie, servato decore osoby swej i tej, do której przyjechał, z pochwałą wszystkiego tamtego dworu. Tylko niektórzy delli signori grandi, że Królewic J.M. nie znając żadnego z nich nie uczynił im takiego honoru, jaki oni rozumieli sobie należeć, a mianowicie, że im czapki nie kazał włożyć, co u nich największa prerogatywa, bo i król

34 K. Stasiewicz, s. 340.

35 Tak dzieje się w dniu 4 kwietnia 1645, kiedy autor jest bezpośrednim świadkiem spotkania cesarza z polskim następcą tronu: „tam uściski z taką łączyły się czułością uczucia, że nie można sobie lepszej wyobrazić między ojcem a synem”. Zob. Podróż królewicza..., s. 400.

36 Tamże, s. 78.

37 Tamże, s. 403.

38 Tamże, s. 78. 
hiszpański, kiedy ich grandami czyni, mówi im: Covred vos, to jest „nakryjcie głowę", i potem już grandami bywają ${ }^{39}$.

W opinii autora Władysław nie popełnił żadnego faux pas, zaś rzekome zaniedbanie wynikło z nieznajomości nie tyle dworskiej etykiety, ile - co zupełnie wytłumaczalne u przybysza po raz pierwszy goszczącego na cudzoziemskim dworze - niemożności zidentyfikowania konkretnych osób i pełnionych przez nich godności.

\section{Królewicz się bawi}

Rozrywki jako element dworskiego życia i urozmaicenie monotonii codziennych obowiązków organizowane były pod każdym możliwym pretekstem: ślubu, narodzin dziecka, sukcesów wojennych czy wizyt gości zagranicznych ${ }^{40}$. Cel urządzania tych imprez bywał różny: okazanie szacunku wobec gościa, demonstracja potęgi państwa i dworu, pokaz osobistych umiejętności panującego ${ }^{41}$. Imprezy takie ciągnęły się niekiedy przez długi czas. Do najczęściej rejestrowanych przez pamiętnikarzy zdarzeń należały wystawne uczty, pokazy taneczne, polowania ${ }^{42}$. Stefan Pac przywołuje na przykład trwające dwa tygodnie „biesiady, konwersacyje z kawalerami przednimi i z paniami, [...] festy i balety"43 urządzone przez infantkę Izabelę na cześć Władysława Wazy. Stopień skonkretyzowania sprawozdania z pokazów tanecznych uzależniony jest od stopnia wyczucia atrakcyjności zdarzenia przez obserwatora, zaś natężenie owego stopnia - proporcjonalnie do statusu uczestników pokazu. Autorzy relacjonujący podróż królewicza wykazują szczególną predylekcję do prezentacji występów członków rodziny cesarskiej. Zachowane zapisy cechuje troska o szczegóły wyglądu zewnętrznego tańczących, ich liczby, jak również obecność komentarza wartościującego. Relacje Stefana Paca i Jana Hagenawa z pokazu „tańców figuralnych” na wiedeńskim dworze akcentują umiejętności

39 Tamże, s. 163.

40 M. Defourneaux, Życie codzienne w Hiszpanii w Wieku Złotym, przeł. E. Bąkowska, Warszawa 1968, s. 44.

41 Zob. B. M. Puchalska, s. 135.

42 Tamże, s. 136.

43 Podróż królewicza..., s. 170. 
cesarzowej Eleonory. Nie braknie także elementu nacechowanego humorem, jak przedstawienie osoby cesarza i królewicza Władysława w roli odźwiernych:

Tego dnia w wieczór Cesarzowa taniec sprawowała i sama w nim była ze dwoma córkami cesarskimi i z piętnastą innych panien - wszystkie w maszkarach. Trwał godzin półtoryj i dalej. Cesarzowa mistrzynią baletu była i pokazała, co w tej sprawie umie z wielką wszystkich spektatorów pochwałą. Potem sama wprzód maszkarę z twarzy zdjąwszy, fraucymerowi toż uczynić kazała. [...]. Panny [...] namordowały były Królewica J.Mci, jako to gościa, bo go prawie nigdy z ręku nie spuszczały ${ }^{44}$.

Nocą cesarzowa urządziła tańce figuralne z 15 paniami ze swego fraucymeru, częściowo wolnymi, częściowo mężatkami. Żeby na tę zabawę tłumnie i bez wyboru nie pchali się mężczyźni, dostęp był przez pokoje Cesarza. I sam Cesarz, stojąc przy drzwiach tylko tego wprowadzał, kogo sam zechciał [...], albo nasz Najjaśn. Królewicz (który podobnie jak cesarz stał ukryty w drzwiach). Największy sukces przed innymi w tańcu, który zwą baletem, zdaniem wszystkich osiągnęła [...] Cesarzowa swą zręcznością, wdziękiem i kunsztem ${ }^{45}$.

Zabieg eksponowania osoby młodego Wazy - jako osoby rozpoznawalnej i darzonej estymą przez swoich gospodarzy - zauważyć można na przykład w prezentacji występów na dworze brukselskim:

Tego wieczora byliśmy na [...] balecie, który kosztem Infanty sprawowano od 12 kawalerów i 12 panien co przedniejszych tamtego dworu, gdzie też Królewic J.M. nieznajomie przyszedł, ale go przecież wszyscy znali i jako panu honor czynili. A śpiewania wszystkie, intermedia odprawowały się in laudem [na chwałę] jego ${ }^{46}$.

Prezentacja postaci gospodarzy imprezy dokonuje się także pośrednio w sytuacjach, kiedy występują one w roli towarzyszy polskiego gościa. I tak

44 Tamże, s. 82.

45 Tamże, s. 83.

46 Tamże, s. 170. 
na przykład sylwetka cesarza pojawia się w opisie rekonwalescencji młodego Wazy pióra Jana Hagenawa: „Królewicz J.M. po raz pierwszy po przyjściu do zdrowia jadł obiad z Cesarzem poza swoją komnatą" ${ }^{47}$. W taki sam sposób dokonano prezentacji sylwetki cesarza Austrii w relacji Stefana Paca: „Królewic J.M. pierwszy raz po chorobie publice jadł z Cesarzem"48. Sprawozdania z polowań oraz innych imprez (strzelanie do celu) nie wykazują obecności elementu naocznego przedstawienia. $Z$ reguły diaryści poprzestają na stwierdzeniach typu: „Te dwa dni na łowiech Cesarz strawił z gośćmi swymi”49, „Dzień minął na polowaniu”50. Konstrukcja powyższych wypowiedzi dowodzi braku emocjonalnego zaangażowania narratora w opisywane zdarzenie, czego konsekwencją jest na przykład brak szczegółów odnoszących się do przebiegu imprezy, rodzaju upolowanej zdobyczy itp. Nieodzownym komponentem narracji jest natomiast - zdecydowanie ukierunkowane „promocyjnie” akcentowanie osiągnięć polskiego podróżnika: „Cesarz urządził publiczne strzelanie do celu, w którym nasz Najjaśń. Królewicz wśród innych zwycięzców otrzymał również swoją nagrodę zręczności” ${ }^{51}$.

Okazją do prezentacji osoby polskiego gościa szerszemu ogółowi są przejażdżki za miasto, na przykład wizyty w popularnych sanktuariach. Wyprawa do Najświętszej Maryi Panny Lacheńskiej (Maria Laach) zorganizowana przez infantkę Izabelę okazała się - w opinii Stefana Paca - zręcznym wybiegiem, mającym na celu przedstawienie królewicza Władysława „ludowi pospolitemu”:

Po obiedzie jeździł z Infantą za miasto do miejsca jednego nabożnego pannie Najświętszej; zową je B[eata] V[irgo] Lachensis. A ten sposób nalazła była Infanta Królewica miastu wszystkiemu ukazać, czego lud pospolity sobie bardzo życzył. Dlategoż nadając drogi i tam jadąc i nazad się wracając inszymi ulicami jachalis ${ }^{52}$.

\footnotetext{
47 Tamże, s. 88.

48 Tamże.

49 Tamże, s. 81.

50 Tamże, s. 82.

51 Tamże.

52 Tamże, s. 170.
} 
Do najbardziej interesujących spostrzeżeń obecnych w zanalizowanym materiale należą zapisy zwyczajów praktykowanych w różnych ośrodkach dworskich. Dotyczą one zarówno sfery osobistej życia panujących, jak również stanowią ważny element charakterystyki dworu jako struktury. Prezentacje indywidualnych zwyczajów towarzyszących na przykład porannej toalecie czy kuracji stanowią uzupełnienie nakreślonych w pamiętnikach i diariuszach portretów. W interesującym nas materiale towarzysze podróży Władysława Wazy odnotowali zabieg puszczania krwi przeprowadzony na osobie chorego królewicza w obecności pary cesarskiej. Relacje Stefana Paca oraz Jana Hagenawa przywołują nieznany w Polsce zwyczaj wręczania przy tej okazji prezentów:

Krew Królewic J.M. puszczał. Cesarz z Cesarzową i Arcyksiążeciem Karlem, nawiedzając tego dnia Królewica, zachowali się podług zwyczaju niemieckiego, u których zwyczaj przyjacioły tego dnia, kiedy krew puszczają, darować czymkolwiek. Toż i oni uczynili53.

Przecinano żyłę Królewiczowi. Cesarz i Cesarzowa skracali Najjaśń. Królewiczowi grając z nim w karty i, zwyczajem niemieckim, dając mu prezenty, życzyli szczęśliwego wyniku spuszczania krwi ${ }^{54}$.

Stefan Pac rozbudowuje swoją relację o szczegóły dotyczące wręczonych polskiemu gościowi prezentów, akcentując elementy interesujące dla odbiorcy tekstu, jak na przykład rodzaj materiału, z którego wykonano dany przedmiot. Podkreślenie wartości podarunku służyło także - zapewne - dodatkowej, pośredniej charakterystyce hojności gospodarzy Władysława Wazy, będącej jednocześnie przejawem nobilitowania i sposobem uhonorowania polskiego królewicza:

Cesarz kubek z kamienia jakiegoś białego, nam nieznajomego, we złoto lekko oprawny. Cesarzowa darowała bindę albo, jak [...] Francuzowie zową, szarpę dosyć pięknej roboty i fetocyją ceglastą z guzem dyjamentowym i dwiema pendecikami także od

53 Tamże, s. 86.

54 Tamże, s. 87. 
dyjamentów i przy tym kilka par rękawic i woreczków ze skórek włoskich haftowanych. Arcyksiążę Karolus dał łyżkę, nóż i widelec z jaspisu, we złoto oprawne ${ }^{55}$.

Hojność panujących podkreślana jest także w momentach pożegnań, w czasie których dochodzi do wymiany upominków. Przedmiotem uwagi narratora stają się na przykład personalia obdarowanych oraz wygląd i wartość otrzymanych prezentów. Towarzyszący królewiczowi Jan Hagenaw pisze:

W wilją wyjazdu naszego przyniesiono nam od Infanty upominki: Książęciu jmci, mnie panu staroście kałuskiemu, panu Denhoffowi i panu Kazanowskiemu. Klejnoty każdemu podług miejsca jego droższe albo tańsze $[\ldots]^{56}$.

Najjaśniejsza Infantka ofiarowała orszakowi Najjaśniejszego Królewicza następujące dary: księciu Radziwiłłowi złoty medal, wyróżniający się drogocennymi kamieniami i swą wielkością; podobny, ale mniejszy, otrzymali panowie Pac, Żółkiewski, Denhoff i Kazanowski; innym dworzanom w służbie Królewicza przekazano podwójne złote łańcuchy ${ }^{57}$.

Stefan Pac uzupełnia narrację, akcentując identyczne zachowania strony polskiej, czyniąc wypadające na korzyść młodego Wazy porównanie:

Tego dnia i nazajutrz od Królewicza JMci wręczano wzajem upominki [...] oficyjałom, których reverendo podano też klejnoty, pierścienie drogie, a drobniejszych czerwonymi złotymi odbywano. Kosztowało to nad 10000 złotych wszystko. Królewic J.M. miał też niektóre galanteryje od Infanty w upominku twego dnia; niewielkiego jednak kosztu ${ }^{58}$.

Analizowane w niniejszym artykule literackie portrety panujących nie są prezentacjami całościowymi. Sylwetki monarchów, ukazywane w kontekście konkretnych zdarzeń, zostały potraktowane wycinkowo, fragmentarycznie,

55 Tamże, s. 87.

56 Tamże, s. 195.

57 Tamże.

58 Tamże. 
z uwzględnieniem elementów interesujących z punktu widzenia autora. Często stosowanym zabiegiem jest ożywianie postaci bohatera poprzez cytowanie jego wypowiedzi, ukazywanie w ruchu, wykonującego takie czy inne gesty. Licznie rejestrowane zachowania pozaprotokolarne mają na celu ukazanie „ludzkiego” oblicza władzy, zmniejszenie dystansu pomiędzy monarchą a czytelnikiem.

Osobne zagadnienie stanowi sposób kreowania postaci Władysława Wazy. Zgodnie z przyjętą przez diarystów strategią ,promocyjną” syn Zygmunta III mimo młodego wieku jest jednostką nietuzinkową, zasługującą na najwyższy szacunek i uznanie. Podtrzymywaniu takiego wizerunku służą sceny wizyt na dworach zachodniej Europy. Przyjmowany z wszelkimi honorami jako królewicz polski i szwedzki, przedstawiciel rozpoznawalnej dynastii, członek rodziny - poprzez matkę - Habsburgów, a także bohater wojen, Władysław posiada wszelkie wymagane umiejętności - dyplomatyczne, językowe czy towarzyskie, pozwalające mu na swobodne odnajdywanie się w skomplikowanych strukturach dworskich.

\section{Bibliografia}

Defourneaux M., Życie codzienne w Hiszpanii w Wieku Złotym, przeł. E. Bąkowska, Warszawa 1968.

Dziechcińska H., Ciało, strój, gest w czasach renesansu i baroku, Warszawa 1996.

Podróż królewicza Władysława Wazy do krajów Europy Zachodniej w latach 1624-1625 w świetle ówczesnych relacji, oprac. A. Przyboś, Kraków 1977.

Puchalska B. M., Obraz dworów zachodnioeuropejskich w polskiej literaturze pamiętnikarskiej XVI-XVII wieku, Białystok 2000.

Rzeczpospolita Wazów (1588-1648-1668). I Kongres Badaczy Epoki Wazów, Olsztyn 6-8 września 2018, red. A. Korytko i in., Olsztyn 2018.

Staropolski ogląd świata. Kultura sacrum, odnajdywanie profanum, red. nauk. B. Rok, F. Wolański, Toruń 2013.

Staropolski ogląd świata. Tożsamość i odmienność, red. nauk. B. Rok, F. Wolański, Toruń 2011.

Wszystko tu najdzie, co wy macie w głowie. Świat prozy staropolskiej, red. E. Lasocińska, A. Czechowicz, Warszawa 2008. 